\title{
The Analysis of the Network of Roads Servicing Fields as Illustrated by the Village of Piątkowa
}

\section{Introduction}

Roads constitute the main element of the land infrastructure prerequisite to conducting any business. They ensure the connection between individual households and the land they use. They also contribute to the spatial arrangement of land. The specific properties of transport network include: width, density, quality (type of paving) and a vertical profile. These features generally affect the use of the owned land. The distribution of road networks influences the spatial arrangement of fields belonging to a given household.

When analysing the road network according to the current spatial and technical condition, the following parameters are taken into account:

- width, length, and the type of road surface,

- the number of plots of land (together with their surface area) serviced by a given road

- road density index.

The above parameters enable the assessment of the condition of roads. Where the assessment is too low it will be necessary to correct road parameters in order to adjust them to transport requirements.

Rules regulating the proper transformation of road networks supporting agricultural transport are based on a number of requirements:

- ensuring the access to every plot or any area of cultivated land and connecting it to the household of residence;

- increasing or decreasing road network density;

- reduction of transport work by providing every plot with an access road, which should be as long as possible and adjacent to at least two sides of the plot;

* University of Life Sciences in Lublin, Faculty of Production Engineering, Department of Engineering, Environmental Development and Surveying, Lublin, Poland

** Rzeszów School of Engineering and Economics, Chair in Cadastre and Geodetic Design, Rzeszów, Poland 
- extension of roads and the removal of such difficulties as: road curves or bends; also designing passing bays for farm machinery to pass one another without collision;

- improving the quality of selected roads by their partial or full paving;

- adapting the road network to the terrain structure and the installation of irrigation and drainage systems thus limiting the destruction of soil [14].

At the beginning of the 1990s the commune of Błażowa began the process of land consolidation. The village of Piątkowa was the first locality in the commune to be subject to the land consolidation. This process lasted from 1990 to 1995 and it was related to the construction and modernisation of the road network.

\section{The Description of the Examined Locality}

The village is located in the commune of Błażowa in the Rzeszów Poviat, $29.2 \mathrm{~km}$ south of Rzeszów (Fig. 1). The village surface area is irregular. It has differentiated altitudes of hill ridges, varied slope gradients as well as diversified landforms: slopes, ditches, landslides, summit planations, and valleys [13].

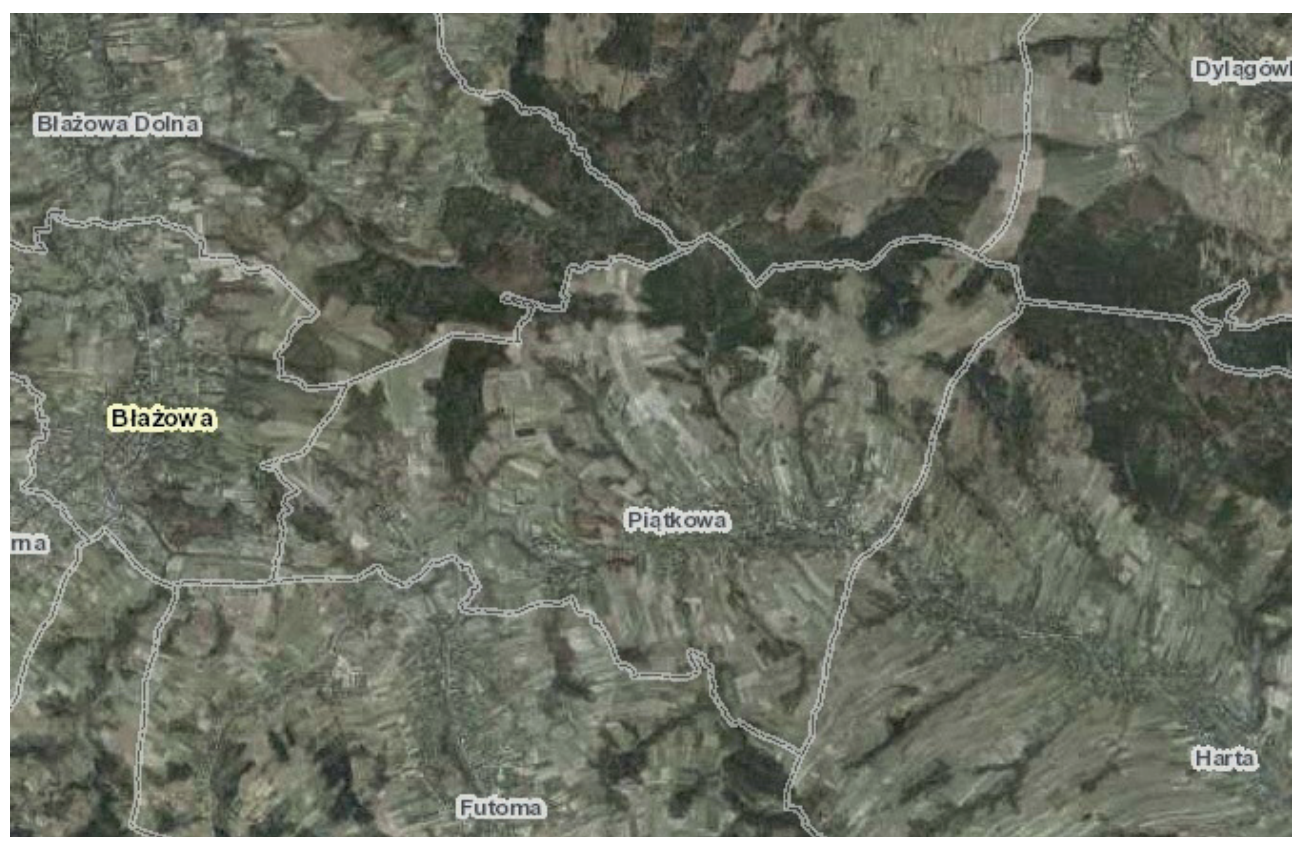

Fig. 1. Spatial layout of the village of Piątkowa

Source: www.geoportal.gov.pl 


\section{The Structure of Land Ownership and Use}

The analysis of the land ownership structure shows that plots owned by natural persons (individuals) dominate in the village of Piątkowa, covering 824.68 ha $(79.9 \%)$. An insignificant percentage share is taken by co-operative land, which is $0.02 \mathrm{ha}$. Plots belonging to the Treasury excluding those leased out for perpetual usufruct cover the surface of 140.71 ha $(13.6 \%)$ and are owned by the State Forests National Forest Holding and Agricultural Property Agency. Plots owned by communes and unions of communes, except for plots leased out for perpetual usufruct, cover 55.79 ha which equals $5.4 \%$ of the village surface area. The land owned by churches and poviats covers the area of $3.18 \mathrm{ha}(0.3 \%)$ and $8.34 \mathrm{ha}(0.8 \%)$ respectively, of the village surface area.

The structure of land use is dominated by cultivated land (59.1\%) with $44.0 \%$ of the total surface of land covered by arable land. The smallest area is taken up by land underneath ponds and ditches. Forests together with wooded and bushy areas cover the surface of $34.2 \%$ with $27.8 \%$ taken up by forests and the remaining $6.4 \%$ by wooded and bushy areas. The built-up and urbanized land covers $6.3 \%$ with the greatest percentage share taken up by transport infrastructure $-5.4 \%$. The land under surface running waters constitutes $0.4 \%$ of the total surface. The type of land use depends on the terrain and climate conditions. Built-up areas come in clusters, which are distributed mainly along supralocal roads. The development of industry and urbanization resulted in the migration of people from the countryside to towns. Therefore, numerous farm households were left without heirs and then granted to the Treasury. These areas were mainly subject to afforestation. Favourable climatic conditions and relatively fertile soil were conducive to agricultural production, which provided source of income to many farmers mainly in the 1980s.

\section{Land Fragmentation}

The fragmentation of land significantly impedes all activities related to soil cultivation, reduces the effectiveness of production, increases environmental degradation as well as obstructs or prevents the use of modern agricultural machinery [6]. The fragmentation of land has to do with a large number of plots belonging to one owner and the decrease in their average surface area. As a result, the cost of land cultivation increases leading to the decrease in the cost effectiveness of agricultural production [1].

The fragmentation of land is typical of the Podkarpackie voivodship. Plots are small and irregular. The studies on land fragmentation in Podkarpackie voivodeship confirm this fact to a certain degree. The plots belonging to individual farm households were analysed in terms of the surface area they occupied and the results of the study revealed a very intense fragmentation of land $[3-5,7]$ and dispersion of land $[6,8,10]$. This problem also applies to land provinces Polish central $[9,11]$ and eastern Polish [12]. 
Using the data from the Land and Property Register, an analysis of the land fragmentation for individually owned land in the village of Piątkowa was carried out (Tab. 1).

Table 1. The structure of the land fragmentation in the case of individually owned land: current situation

\begin{tabular}{||c|c|c|c|c|c|c||}
\hline \multirow{2}{*}{ No. } & \multirow{2}{*}{$\begin{array}{c}\text { Surface area of } \\
\text { land } \\
\text { [ha] }\end{array}$} & \multicolumn{4}{|c|}{ Plots in the range } & $\begin{array}{c}\text { Average } \\
\text { surface area of } \\
\text { a plot } \\
\text { [ha] }\end{array}$ \\
\cline { 5 - 8 } & number & [\%] & $\begin{array}{c}\text { total surface area of } \\
\text { plots }\end{array}$ & [\%] & 0.06 \\
\hline \hline 1 & up to 0.10 & 669 & 28.2 & 37.26 & 4.5 & 0.15 \\
\hline 2 & $0.11-0.20$ & 464 & 19.5 & 69.04 & 8.4 & 0.26 \\
\hline 3 & $0.21-0.30$ & 298 & 12.5 & 76.79 & 9.3 & 0.35 \\
\hline 5 & $0.31-0.40$ & 218 & 9.2 & 75.34 & 10.6 & 0.45 \\
\hline 6 & $0.41-0.50$ & 194 & 8.2 & 87.22 & 34.6 & 0.69 \\
\hline 7 & above 1.01 & 117 & 4.9 & 193.77 & 23.5 & 1.66 \\
\hline & Total & 2375 & 100.0 & 824.67 & 100.0 & 0.35 \\
\hline
\end{tabular}

Source: own calculations based on the data from the Land and Property Register

The largest group consists of parcels up to 0.10 ha. It includes 669 plots with a total surface area of 37.26 ha. The second group is composed of 464 plots covering 69.0 ha. There are 298 and 218 plots in the third and the fourth group, respectively, with the area of 76.79 and 75.30 ha. The fifth group includes 194 plots covering the surface of 87.22 ha. The distribution of plots in the groups mentioned above revealed the decline in the number of plots together with the increase in the range, therefore, a decision was made to increase the spatial range from 0.51 to 1.00 ha. The number of plots in this group is 415 with a total surface area of 285.24 ha. The last group consists of plots exceeding 1.01 ha and they make a total of 117 plots.

The average surface area of a parcel is 0.35 ha, which is relatively small, but one should take into account the fact that plots are located in foothill areas, which, to some extent, prevents the delineation of large plots. The value of the average plot surface is lowered by a large number of plots with the area of up to 0.10 ha, which are mainly covered by forests. The spatial layout of land fragmentation is illustrated in Figure 2. 


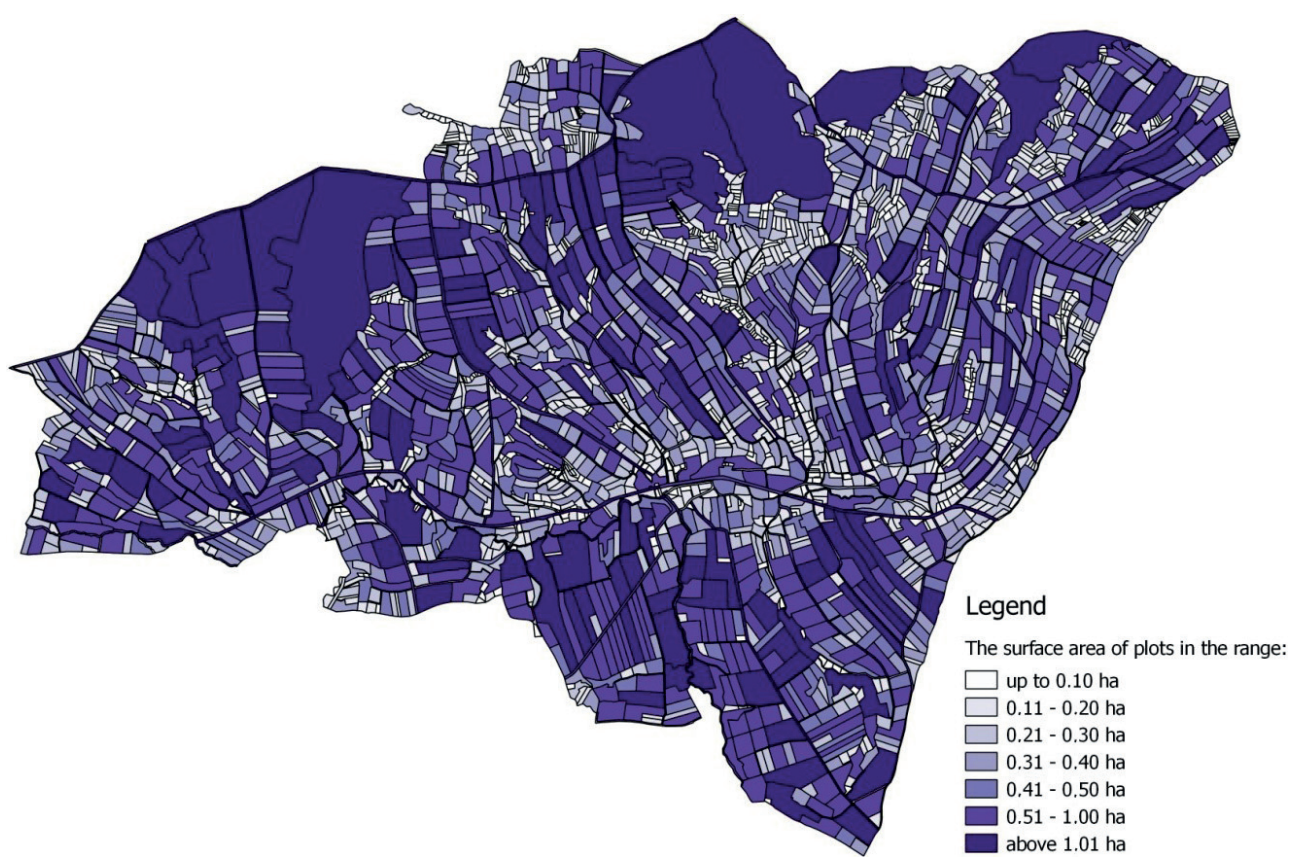

Fig. 2. The spatial layout of land fragmentation in particular ranges

\section{The Analysis of the Network of Roads Providing Direct Access to Fields}

The communication system plays a particularly important role in the proper functioning of farm households. The correct location of roads which are part of the internal infrastructure used by agricultural transport should ensure a direct access to each separate part of cultivated land as well as provide the connection to residential households [2].

The village of Piątkowa has a road network consisting of 247 roads with 5.08 ha of poviat roads (6 roads) and 50.96 ha of communal roads, which in their entirety or in part are used for purposes related to farming. The only exception is road no. 944 (0.06 ha), which provides access to the cemetery. The total area of all roads is $56.1 \mathrm{ha}$, which equals $5.4 \%$ of the surface of the investigated village. Roads providing direct access to fields are composed of 240 parcels-roads. Their total length is $77,268.7 \mathrm{~m}$, with 59,077.4 m used in in full, which equals $76.5 \%$ of their total length. 15,537.9 m are used periodically and they represent $20.1 \%$ of the total length of these roads. The roads which are not used at all measure $2,654.1 \mathrm{~m}$, which is $3.4 \%$ of the total length.

The research carried out reveals that roads used in agricultural transport service the area of 830.52 ha, which represents $80.4 \%$ of the total surface area of the village. In total, these are 1,751 plots, assuming that one plot is serviced by one road. This 
assumption was adopted because some parcels border more than one road, and as a result the total area of land serviced by these roads would significantly exceed the surface of the village. The number of plots without access to any road has increased and so did the surface area. According to the data obtained from the Land and Property Register, the number was 701, however upon inspection, the number has increased to 736 plots, with the total area of 114.5 ha, which makes up $11.1 \%$ of the village surface area.

Roads used in agricultural transport do not service all plots, including those situated along the main road. This road (a fragment of poviat road no. 615) services 118 plots with the total surface area of 26.98 ha, which is $2.6 \%$ of the total surface area of the village.

Some plots situated along the village border are serviced by roads belonging to neighbouring localities. They are 13 with a total surface area of 4.62 ha $(0.4 \%$ of the total area). The spatial layout of the road network in the village of Piątkowa is illustrated in Figure 3.

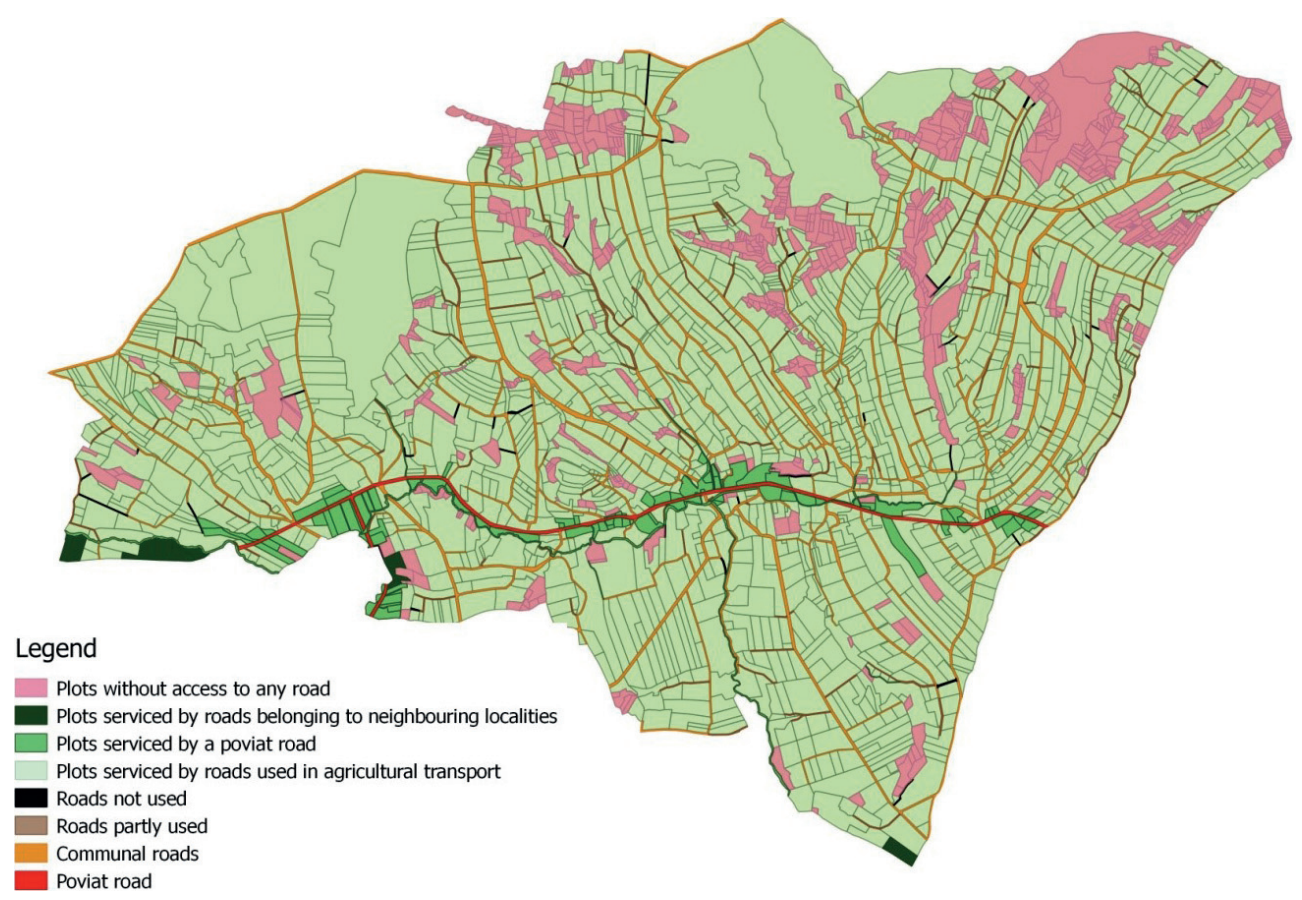

Fig. 3. Spatial layout of road network

As for the technical condition of roads in the village of Piatkowa, there are roads with paved or unpaved surface. Paved roads make up 2,5474.4 m which equals $33.0 \%$ of their total length. These are mainly roads leading from residential 
households and accessing cultivated fields which are used in their entirety. As an example of such a road one can consider road no. 2027, which is covered with asphalt for $275.2 \mathrm{~m}$, while the rest of it, i.e. $1269.8 \mathrm{~m}$, is covered with menilite slate. A similar situation is true in the case of road no. 570, which is covered with asphalt until the last building structure situated by the road $(167.6 \mathrm{~m})$, while its remaining fragment, which measures $1596.7 \mathrm{~m}$, is paved with gravel.

Where necessary, agricultural roads are paved and modernised through the construction of drains and culverts. In 2012, the following roads were modernised: road no. 508, no. 507, no. 503 and no. 2590 and then, one year later, road no. 466 and a part of road no. 422. Road no. 2083 was partly modernised in 2014. Unpaved roads measure $51,827.2 \mathrm{~m}$, which equals $67.0 \%$ of the total length or roads. These are unpaved roads but they ensure unobstructed access to fields.

A detailed analysis of roads revealed the presence of roads which are no longer in use. These roads are of no particular importance as is in the case of road no. 391. In the place where one may expect a road, there is a steep slope and the neighbouring plots are bushy and covered with shrubs.

The analysis of roads providing a direct access to fields was aimed not only at assessing them in terms of length, width or technical condition, but also at estimating the number of plots a given road is able to service and determining the road density index (Tab. 2).

Table 2. The structure of plots serviced by roads

\begin{tabular}{|c|c|c|c|c|c|c|}
\hline No. & $\begin{array}{c}\text { Range } \\
\text { of plots } \\
\text { serviced by } \\
\text { roads }\end{array}$ & $\begin{array}{l}\text { Number } \\
\text { of roads } \\
\text { within the } \\
\text { range }\end{array}$ & $\begin{array}{l}\text { Percentage } \\
\text { share of the } \\
\text { number of } \\
\text { roads within } \\
\text { a given range }\end{array}$ & $\begin{array}{l}\text { Total number } \\
\text { of plots within } \\
\text { a given range }\end{array}$ & $\begin{array}{l}\text { Percentage } \\
\text { share of plots } \\
\text { serviced by } \\
\text { roads }\end{array}$ & $\begin{array}{c}\text { Average } \\
\text { number } \\
\text { of plots } \\
\text { accounting } \\
\text { for one road }\end{array}$ \\
\hline 1 & up to 5 & 147 & 61.3 & 319 & 18.2 & 2 \\
\hline 2 & $6-10$ & 44 & 18.3 & 345 & 19.7 & 8 \\
\hline 3 & $11-15$ & 19 & 7.9 & 238 & 13.6 & 13 \\
\hline 4 & $16-20$ & 9 & 3.8 & 157 & 9.0 & 17 \\
\hline 5 & $21-25$ & 7 & 2.9 & 161 & 9.2 & 23 \\
\hline 6 & $26-30$ & 1 & 0.4 & 27 & 1.5 & 27 \\
\hline 7 & $31-35$ & 5 & 2.1 & 171 & 9.8 & 34 \\
\hline 8 & $36-40$ & 3 & 1.3 & 108 & 6.2 & 36 \\
\hline 9 & $41-45$ & 3 & 1.3 & 126 & 7.2 & 42 \\
\hline 10 & over 46 & 2 & 0.8 & 99 & 5.7 & 50 \\
\hline \multicolumn{2}{|c|}{ Total } & 240 & 100.0 & 1751 & 100.0 & - \\
\hline
\end{tabular}

Source: own calculations based on the data from the Land and Property Register 
The obtained data indicate that roads service a significantly varied number of plots, on average from 2 plots from the first group, which consists of 147 roads (61\% of all roads in agricultural transport), up to 50 plots from the last group.

The final step of the analysis was to determine the road density index $\left(G_{d}\right)$, which is defined as the ratio of the length of roads expressed in meters $\left(l_{d}\right)$ and the size of road-serviced areas expressed in hectares $(P)$ :

$$
G_{d}=\frac{l_{d}}{P}
$$

The length of all roads used in agricultural transport in the investigated village is $77,268.7 \mathrm{~m}$, including $2,654.1 \mathrm{~m}$ of roads which are no longer in use. When deducting these values one will obtain the actual length of roads used in agriculture, which is $74,614.6 \mathrm{~m}$. The result obtained and the surface of the serviced area (830.5 ha) are inserted in the formula:

$$
G_{d}=\frac{7,4614.6 \mathrm{~m}}{830.5 \mathrm{ha}}=89.8 \mathrm{~m} / \mathrm{ha} .
$$

The obtained road density index shows that $89.9 \mathrm{~m}$ of roads account for the area of 1.0 ha. According to Hopfer, the optimal value of road density index should amount to $21.5 \mathrm{~m} / \mathrm{h}$. The index exceeded the optimum value 4 times, which means that the network of roads is very dense. The value of the index depends to a large extent on the terrain structure, and also on the structure of the cultivated land, the ownership structure and the infrastructure of the area [14].

\section{Summary and Conclusions}

Based on the studies carried out, the following conclusions were achieved:

1. The largest share in the ownership structure belongs to natural persons. Depending on the size of the area owned (larger than 1 ha of cultivated land), the Agency for Restructuring and Modernisation of Agriculture shall pay due payments to farmers, the so-called direct payments. This is supposed to serve as an encouragement to carry out agricultural business, thanks to which the land will retain its fertility and the number of wastelands will decrease.

2. The analysis of the individually-owned land shows a high degree of fragmentation, although the 1990s saw processes aimed at land consolidation. The situation is to a certain degree the result of the terrain structure, which makes it difficult to delineate large plots. The smallest plots (up to $0.10 \mathrm{ha}$ ) are mainly forests, which were not taken into account during the consolidation. 
3. The structure of land use indicates the largest share of cultivated land, which is closely linked to the ownership structure. The manner of land use depends on the terrain structure and climate conditions.

4. The analysis of the network of roads servicing fields revealed its high density. According to the literature, the value of the road density index is affected by the aspects mentioned and presented above. Also, taking into account the consolidating processes completed in 1995, on the assumption that they were executed correctly, high density of roads as well as the problem of land fragmentation mentioned above could be related, to a large extent, to the structure of the terrain.

The existing condition of agricultural roads in the village of Piątkowa may be described as good. Despite the fact that a large number of roads is not paved, they are fully passable. In addition to this, an on-site survey did not reveal any damaged roads, because they are modernised as often as it is needed and financially feasible.

\section{References}

[1] Harasimowicz S., Janus J.: Strefy dostepności do działek uwzględniajace zmiany ich dtugości oraz odległości między drogami. Infrastruktura i Ekologia Terenów Wiejskich, nr 01, 2012, pp. 165-175.

[2] Hopfer A., Urban M.: Geodezyjne urządzenie terenów rolnych. PWN, Warszawa 1984.

[3] Leń P.: Analiza rozdrobnienia gruntów indywidualnych na przykładzie powiatu Brzozów. Infrastruktura i Ekologia Terenów Wiejskich, nr 01, 2010, pp. 65-74.

[4] Noga K., Leń P.: Analiza rozdrobnienia gruntów indywidualnych we wsiach powiatu Brzozów. Infrastruktura i Ekologia Terenów Wiejskich, nr 03, 2010, pp. 55-64.

[5] Leń P.: Określenie pilności potrzeb prac scalenia $i$ wymiany gruntów we wsiach powiatu Brzozów. Infrastruktura i Ekologia Terenów Wiejskich, nr 03, 2011, pp. 7-16.

[6] Leń P.: Prawidłowości w rozmiarze występowania gruntów różniczan zamiejscowych na przykładzie wsi w powiecie Brzozów. Infrastruktura i Ekologia Terenów Wiejskich, nr 01, 2012, pp. 137-145.

[7] Len' P., Dzhyadosh D., Kovalyshyn O.: Vykorystannya prohramy Quantum GIS pid chas analizu prostorovoyi struktury sela Ol'Shanytsya [День П., Джядош Д., Ковалишин О.: Використання програми Quantum GIS під час аналізу просторової структури села Ольшаниця]. Seriya: Ekonomika APK, no. 22 (2), 2015, pp. 151-158, [on-line] irbis-nbuv.gov.ua [access: 25.09.2015]. 
[8] Leń P., Matysek I., Kovalyshyn O.: Dimensions of Plots Belonging to Out-of-village Owners in the Village of Będziemyśl, Commune of Sędziszów Małopolski. Geomatics and Environmental Engineering, vol. 9, no. 2, 2015, pp. 63-70.

[9] Wójcik G., Leń P.: Spatial Development of Agricultural Land Division throughout the Ages in Villages of the Opoczno County. Geomatics and Environmental Engineering, vol. 9, no. 3, 2015, pp. 95-107.

[10] Leń P., Mika M., Wójcik-Leń J.: Estimation of the size of the external Land patchwork based on test areas in podkarpackie voivodship in Poland. Geomatics, Landmanagement and Landscape, no. 1, 2016, pp. 65-74.

[11] Leń P., Mika M.: Ranking przeznaczenia obszarów do prac scaleniowych, ze względu na rozmiary szachownicy gruntów, na przykładzie gminy Sławno. Infrastruktura i Ekologia Terenów Wiejskich, nr II/1, 2016, pp. 287-298.

[12] Król Ż., Leń P.: Szachownica gruntów indywidualnych wyznacznikiem pilności wykonania prac scalenia i wymiany gruntów. Infrastruktura i Ekologia Terenów Wiejskich, nr II/1, 2016, pp. 311-322.

[13] Plan Rozwoju Lokalnego Gminy Błażowa, June 2004, [on-line:] www. bip. blazowa.itl.pl [access: 25.09.2015].

[14] Radziszewska W., Jaroszewicz J.: Ocena istniejacej sieci dróg transportu rolnego na obszarze wsi poddanej pracom scaleniowym. Acta Scientiarum Polonorum Geodesia et Descriptio Terrarum, vol. 11 (3), 2012, pp. 17-34.

[15] Siuta J., Żukowski B.: Rozwój i potencjalne zagrożenia agroekosystemów. Czesść IV: Zagrożenia agroekosystemów. Ochrona Środowiska i Zasobów Naturalnych, t. 21 , nr 2 (43), 2010, pp. 80-103. 